theory that phototropism represents a special case of photo-growth reactions (1913). The succeeding period was devoted to exact measurements of growth, especially in Avena coleoptiles, as influenced by illumination and gravity (1919-26). Although a large amount of data was collected, it did not help much in visualising an internal mechanism of growth and tropisms.

The whole aspect and technique of the problem were changed, however, by the isolation of the growth substance (auxin) by Went's elder son (F. W. Went, 1927), and by his successful attempts to elaborate a physiological method of quantitative analysis of this growth substance. A large number of papers was published in the succeeding years on the relation of auxin to phototropism and geotropism, its distribution and transport, its formation in the root and its influence on the plasticity of the cell wall. Further, the chemical nature of auxin was revealed by Kögl and his collaborators (Haagen Smit, Miss Erxleben), also at Utrecht in the University Chemical Laboratory.

It was not in biology alone that Went was a man of outstanding importance. A member of the Royal Academy of Sciences, Amsterdam, since 1898, he was elected president in 1921. In this capacity he succeeded Lorentz, who strove after the War to bring together again scientific men of different nations. Went followed the example of his great predecessor with the same idealism, and finally succeeded in getting international scientific relations re-established to a large extent. Went thus played an important part in international scientific congresses.

Went was at the height of his scientific importance and international fame when he died. He retired from the chair of botany in Utrecht in July, 1934, and took an active part, until his death, in the preparations for the International Botanical Congress, of which he was president-elect. On several occasions during his life, for the last time on the occasion of his seventieth birthday, appreciation of his work was shown: in 1930 he was given the honorary degree of doctor of science of the University of Cambridge ; in 1931 he was elected a foreign member of the Linnean Society of London, and in 1933 of the Royal Society. In Went we have lost a man of great qualities : his death will be deplored far beyond the boundaries of his own country.

\section{Miss Nina F. Layard}

WE regret to record the death of Nina Frances Layard, archæologist, which took place after an operation at the age of eighty-two years. She was a daughter of the Rev. C. C. Layard, rector of Combe Hay, Bath, and a niece of Sir Austen Layard, the excavator of Nineveh.

Miss Layard was not only the first woman to be elected a fellow of the Society of Antiquaries, but she was also one of the first of those women who took up seriously and earned distinction in the scientific study of archæology in the field. She was for long one of the most prominent of the students of East Anglian archæology, especially in the neighbourhood of
Ipswich, holding that position almost as much by her success in stimulating the enthusiasm of others as by her own researches. These, however, especially in her studies of the industries of the palæolithic period, brought her no small reputation outside local circles, and on more than one occasion her work received the public commendation of Sir John Evans.

In addition to her finds of the palæolithic period, of which she submitted accounts to the British Association or published in the Journal of the Royal Anthropological Institute and other archæological publications, Miss Layard made an interesting and unusual discovery of what she held to be a prehistoric communal kitchen and a neolithic mining area, and superintended the excavation of an Anglo-Saxon cemetery, the relies from which are to be found in the Ipswich Museum. She also did much work on the investigation of remains of the Roman and medieval periods. In addition to her contributions to the Journal of the Royal Anthropological Institute, the Proceedings of the Prehistoric Society of East Anglia and other publications, Miss Layard was the author of a history of Ipswich School, of "Seventeen Suffolk Martyrs", and of two volumes of verse.

\section{Dr. C. F. Marbut}

SoIr investigators all over the world will learn with deep regret of the death of Dr. C. F. Marbut at Harbin. Early in August, he had attended the International Congress of Soil Science at Oxford, and had presided over the Section of Soil Classification and Mapping. He did not accompany the members on their excursion around Great Britain, but left instead for China, where he was to spend a year studying the soils and advising generally in regard to their mapping. Afterwards he was to go to Rome to work at the International Institute of Agriculture on the preparation of a map of the world's soils. But he was struck down by pneumonia on his voyage and died at Harbin.

Marbut began his career as a teacher in Nebraska, then became professor of geology in the Missouri University. He joined the Bureau of Chemistry and Soils of the United States Department of Agriculture at Washington and by 1912 he was appointed chief of the Division of Soil Survey : it was here that his best work was done.

Up to the time that Marbut took charge, the American soil surveys had been mainly based on the mechanical analyses of the surface soils. Marbut was essentially a field man, and discarded this analytical basis for a study of the characteristics of the soil as revealed by direct examination of the profile. This was, of course, accompanied by chemical and mechanical examinations, but the perspective was different: the interest lay in the morphology of the soil rather than in the units out of which it was made. This was in accordance with the developments of the subject being made in Russia by Glinka and others, the importance of which he recognised by translating into English the German edition 